\title{
INSTRUMENTS AND FIANANCIAL PERFORMANCE INDICATORS OR THE CAPITALIZATION OF ACCOUNTING INFORMATION FROM THE PROFIT AND LOSS ACCOUNT - MEANINGS USEFUL TO MANAGEMENT
}

\author{
Alina-Teodora CIUHUREANU \\ “Nicolae Bălcescu” Land Forces Academy, Sibiu, Romania \\ alinaciuhureanu@yahoo.com
}

\begin{abstract}
For the capitalization of accounting information in view of financial performance analysis of the company, management must operate at least based on intermediate management balance, the cash flow, breakeven point and earnings per share, indicators established, first, by using the information in the statement Profit and Loss Account. Based on these considerations, the paper addresses, by the exploratory research, the main constructions based on financial accounting information presented in the profit and loss account, the objective being to show the opportunities and limitations of information generated for management.
\end{abstract}

Keywords: accounting information, intermediate management balances, profitability, financial performance, management

\section{Intermediate management balances}

Intermediate management balances represent a cascade of financial indicators by which management has the possibility of assessing financial performance.

In essence, by the construction of intermediate management balance (IMB) management has the opportunity to know in detail the formation of the net result for the financial year and the contribution of each activity [1], [2]. Given the purpose of this paper, based on literature study and the expression of our own views, the IMB meanings useful to management are shown below.

Profit margin. To provide useful meanings to management, profit margin should be analyzed in time according to the inventory turnover, compared with values obtained by major competitors, divided by types of products or activities [3]. A reduction in the margin should have the effect of increasing sales, basically leading to a reorientation of the trade policy, which is not always true in practice as there are the components of products / goods traded.

Production of the financial year is inevitable but ambiguous indicator specific to the production / performance of work / delivery of services. The main limit is that the production value cannot reflect the financial reality, the result being subjected to the influence of the method used for stock assessments.

For management, value added, an indicator that eventually contributes to the GDP [4], is essential to have a positive value, since a negative value can mean the destruction of capital invested. In such a situation a rethinking of the business, strategy (if any) and policies is required, maintaining a negative value added resulting in the shutting down of the business [5].

Gross operating surplus (GOS) expresses the resources of exploitation to be used by managers both in order to maintain the level 
of activity and of its development. Under the approach of the dictionary of terms developed by the OECD, GOS is the available resources that allow the entity to pay suppliers, taxes and fees, finance investments [6]. GOS is the fundamental financial resource of the entity and is measured before decisions on depreciation and financial expenses arising from the funding policy, the indicator being really "raw", which allows top managers a comparison over time or tracking the share of the value added (or turnover) which will be intended for remuneration of production factors [7].

The operating result is presented as such in the Profit and Loss Account, being the first main element reflecting economic profitability. The level of the operating result gives managers information on the size of resources from operations that the company can rely on for covering its financial expenses [8]. The current result concerns the effectiveness of all operational and financial activities, as presented in the Profit and Loss Account.

Gross profit is included in the Profit and Loss Account and is not part of the actual balances' picture. It provides information on the result before tax.

The net result obtained after taxation contributes to the management options for future investment, financing and dividend policies.

\section{Profitability - meanings useful to management}

The company's performance is identified through profitability, namely through its ability to make profit [9]. In literature and in practice, the profitability can be known using several types of rates determined either based on data from the annual financial statements, or by a ratio such as outcome / effort [10].

Thus, calculating the return on sales, the accounting information is able to provide the management assessment opportunities for recovery efficiency in terms of costs and prices. The positive dynamics has favorable significance because it shows that profit index exceeds annual turnover index. In order to obtain good commercial returns the possibility of increasing sales can be discussed, adopting measures to accelerate stock rotation, tampering costs. Common in foreign literature, net commercial rate of return (Return on Sales) is the easiest to calculate for external users, using only data from the profit and loss account, without requiring information from the management accounting. It should be noted that, since the net result is affected by the incidence of taxation, the informational value of commercial profitability rate thus calculated is limited; moreover, affecting the net result by the financial and extraordinary result leads to the alteration of assessing trade policies through the rate calculated according to the model in question. Consequently, the operation result is considered to be an indicator more relevant for building commercial profitability rate [11].

The Rate of Economic Return, by the establishment hereof, the management aims at economic efficiency of capital allocated to the productive activity of the company, expresses either the level of remuneration of capital invested [12], or how to reward the risks assumed by existing investors by investing the capital. Depending on the value obtained for this ratio, managers are able to guide themselves in adopting the financing decision in terms of choosing between long-term and short term financing. The rate of economic return should be also analyzed depending on the rate of inflation / consumer price index. To be able to pay investors at a minimum level of efficiency in the economy (market interest rate) and to cover economic and financial risk assumed by the company's "suppliers" of equity [13], [14] it is necessary that the rate will be higher than inflation.

Return on consumed resources, also called the return on costs and determined by 
dividing an indicator of outcome to the consumption of resources needed to acquire it [15], provides information on the effectiveness of effort resulted in costs being a picture of the correlation between profit attributed to the turnover and total costs employed. Rates can be calculated globally, at the firm level, or on specific components of expenditure structure and purpose.

The financial rate of return shows the remuneration of company's owners through dividend distribution to them and by the increase of reserves, being an accounting measure of profitability given that equity estimation is based on accounting data, i.e. an assessment from the past. It is also necessary because it allows managers to estimate cash flows [16]. To obtain an increase in financial return, managerial decisions are required, aimed at enhancing return on sales (change in net profit faster than turnover), accelerating rotation on capital etc. In general management it is not simply enough the calculation of economic and financial rates of return but is necessary to analyze interdependencies between them.

\section{Expression of financial performance for companies traded on the stock exchange}

In assessing the financial performance, investors call for the calculation of specific indicators, which prove beneficial for management, too.

Earnings per share - EPS [17], in dynamic analysis, shows the company's capacity to maintain the growth rate of profit over time, which interests investors the most. An increasing trend of EPS will enhance investors' preferences for these shares, which will also increase their rate. Typically, EPS developments are analyzed in conjunction with other indicators' development, especially with the evolution of turnover relative to the number of shares outstanding [18]. We believe that the determination of earnings per share is an essential objective in management, especially given that it wants to move into the international capital market, to attract new investors, to operate on the principles of corporate governance. Moreover, the importance of the indicator was recognized in our country by adopting OMPF 881/2012 [19].

Dividends Per Share - DPA provides information on the profitability of shortterm shares, sought mainly by minority investors [20].

The rate of dividend distribution provides information on the profit for the year distributed to existing investors. The size of this rate is interesting because it provides information on the dividend policy adopted by management, respectively for the interest in maintaining self-financing possibly for future investments which could lead to a better picture of both the management team and the entity in general; the reverse may, however, occur - the dissatisfaction of shareholders who primarily aim to win through dividend (distribution rate tends towards 0 ) interest to satisfy shareholders (distribution rate tends towards 100\%), interest in being best friends of shareholders (distribution tends rate is over 100\%) [21].

The ratio between the market value and the accounting value (Market to Book Ratio) shows confidence that financial markets gives to the management team. However, the limitation of this indicator is given by the economic context because, despite good management, in times of crisis and economic instability, the ratio may be less than a unit.

In terms of Economic Value Added - EVA, the term is a registered trademark of Stern Stewart \& Co. The indicator reflects the surplus value created from operating activities after the costs of invested capital and corporate tax has previously been covered. A variant of EVA is the refined economic value added (REVA) which seeks to eliminate accounting distortions taking into account the market value to determine the cost of invested capital [22]. Management should pay attention to this 
indicator because it can be taken into consideration when determining bonuses for managers.

Market Value Added - MVA is an indicator integrated in the improvement of the company's overall management, being calculated simpler compared to EVA, namely by the difference between the market value of capital invested and their carrying amount [23].

PER Index (Price Earnings Ratio) shows willingness of investors to pay for obtaining a monetary unit of the issuer's profit or whenever investors are willing to buy profit per share PER is a way to measure the cost of the estimated title based on its value, reflected solely by the last net profit considered, usually of the most recently completed financial year, indicating the number of years for recovering investment if net profit would be distributed entirely on dividends [24].

\section{Conclusions}

Given the meanings highlighted, we conclude that the need to establish intermediate management balances is required both by the information valences for management and the preparation of national accounts. The utility of IMB picture for the management derives mainly from the fact that they highlight specific indicators of performance, on levels, which are not included directly in the profit and loss account [25]. Also, management utility is given by the possibility that the IMB indicators are used in the preparation of financial documents necessary to perform forecasting and control-evaluation functions given that liquidity is and will be a major problem.

Regarding profitability indicators as the image of financial performance, the opinions of specialists, according to whom they are only financial indicators that do not express all the factors behind profit, listing as examples the performance of employees, social climate, labor productivity, relationships with the competitive environment etc., does not resist if the argument that the company evolves as an open economic system in the conduct and results of which there are all factors that determine revenue, expenditure and hence profits. As a result, rates of return have useful meanings for management, expressing, indeed synthetically, the results obtained [26], [27].

As already stated, for the companies traded on the stock exchange, it is necessary, for a proper assessment of financial performance, to calculate specific indicators through which current and potential investors obtain additional information regarding the evolution of companies traded. Moreover, these indicators can be assimilated to a global financial language, their presence being found globally and not just nationally, which can result in attracting (or not) potential investors.

\section{References}

[1] Mironiuc Marilena, Analiza performanţelor economico-financiare ale intreprinderii. Soldurile intermediare de gestiune, Contabilitatea, expertiza şi auditul afacerilor, nr. 5/2002, pp. 32-40

[2] Mica Ivona Gabriela, Importanţa raportărilor financiare în managementul firmei, Contabilitatea, expertiza şi auditul afacerilor, nr. 10/2009, p. 40

[3] Boby Costi, Analiza pe baza tabloului soldurilor intermediare de gestiune, Studia Universitatis "Vasile Goldiş" Arad, Seria Ştiinţe economice, 21/2011, p. 520

[4] Balteş Nicolae (coord.), Analiza economico-financiară a întreprinderii, ediţia a II-a, Ed.’Lucian Blaga" University Publishing House, Sibiu, 2013, p. 71

[5] http://www.accountingtools.com/economic-value-added, accesed may 2015

[6] http://stats.oecd.org/glossary/detail.asp? ID=1178, acceses may 2015

[7] Hubert de La Bruslerie, Analyse financière. Information financière et diagnostic, 
Dunod, Paris, 2002, p. 145-146

[8] Dragotă Victor, Ciobanu Anamaria, Obreja Laura, Dragotă Mihaela, Management financiar. Vol I: Analiză financiară şi gestiune financiară operaţională, Economică Publishing House, Bucureşti, 2003, p. 184

[9] Petrescu Silvia, Performanţă şi risc în analiza financiară, Analele Ştiinţifice ale Universităţii "Alexandru Ioan Cuza" din Iaşi, nr. 50-51/2005

[10] Petrescu Silvia, Analiză si diagnostic financiar-contabil: ghid teoretico-aplicativ, CECCAR Publishing House, Bucureşti, 2008, pp. 144-146

[11] Vasiu Diana, Analiza performanţelor financiare la societăţile listate şi tranzacţionate la Bursa de Valori Bucureşti, teză de doctorat, 2015, p. 35

[12] Vasilache Vasile, Rata rentabilităţii economice - indicator de eficiență a capitalului economic, Contabilitatea, expertiza şi auditul afacerilor, nr. 6/2009, p. 34

[13] Stancu Ion, Finanţe. Teoria piețelor financiare. Finanţele intreprinderilor. Analiza şi gestiunea financiară. Economică Publishing House, Bucureşti, 1997, pp. 494-497,

[14] Balteş Nicolae, Analiză şi diagnostic financiar, "Lucian Blaga" University Publishing House, Sibiu, 2010, p. 44

[15] *** Ratele de rentabilitate - expresie relativă a rentabilităţii, www.ase.ro/upcpr/.../analiza_performantelor2.doc, accesat iulie 2015, pp. 4-5

[16] Ciuhureanu Alina Teodora, Management financiar, Lucian Blaga" University Publishing House, Sibiu, 2009, pp. 149-151

[17] IAS 33 "Rezultatul pe acţiune - Earnings per Share", available online at http://eifrs.ifrs.org/eifrs/bnstandards/en/2012/ias33.pdf, accesat noiembrie 2012

[18] Hurduzeu Gheorghe, Pieţe şi burse internaţionale de valori, Pro Universitaria Publishing House, Bucureşti, 2006, p. 56

[19] Ordinul Ministrului Finanţelor Publice nr. 881/25.06.2012 privind aplicarea de către societăţile comerciale ale căror valori mobiliare sunt admise la tranzacţionare pe o piaţă reglementată a Standardelor Internaţionale de Raportare Financiară, M.Of. nr. 424/26.062012, cu modificările ulterioare

[20] Burja Camelia, Eficienţa investiţilor financiare, Annales Universitatis Apulensis Series Oeconomica, nr. 8/2006, vol. 3, p. 1

[21] *** Ghidul investitorului. Investiţiile pe piaţa de capital, Romcapital, p. 5

[22] Cîrciumaru Daniel, Siminică Marian, Valoarea adăugată economică rafinată indicator de măsurare a performanţelor firmelor, Theoretical and Applied Economics, supplement, 2009, pp. 206-208

[23] Berheci Maria, Rezultatul contabil, rezultatul economic şi valoarea creată - indicatori de apreciere a performanţelor intreprinderii, Contabilitatea, expertiza şi auditul afacerilor, nr. 8/2010, p. 19

[24] Vasiu Diana, Analiza performanţelor financiare la societăţile listate şi tranzacţionate la Bursa de Valori Bucureşti, teză de doctorat, 2015, pp. 170-171

[25] Dumitru Mihaela, Ţaicu Marian, Săvoiu Gheorghe, The Use of Intermediate Management Balances as a Performance Management Tool in Electricity Companies, Revista Română de Statistică, Supliment nr. 1/2014, p. 25

[26] Bogdan Ioan, Tratat de management financiar-bancar, Economică Publishing House, Bucureşti, 2002, p. 370

[27] Bogdan Ioan, Management financiar, Universitară Publishing House, Bucureşti, 2004, p. 306 